\title{
Leading the Construction of Fire - fighting Colleges with the Goal of Strong Army
}

\author{
Jiangping Liu \\ Public Security Fire Force College, Kunming 650208, China
}

\begin{abstract}
Keywords: Listen to the party command to win the battle style fine fire school.
\end{abstract}
\begin{abstract}
Since the 18th National Congress of the Communist Party of China, General Secretary Xi Jinping has persisted in and developed socialism with Chinese characteristics and realized the great rejuvenation of the Chinese nation. He has put forward a series of major strategic thoughts around the army and led us to realize the revival and construction of the Chinese nation Of the people's army, the construction of first-class fire school on the journey to stride forward. Since the 18th National Congress of the Communist Party of China, General Secretary Xi Jinping has persisted in and developed socialism with Chinese characteristics and realized the great rejuvenation of the Chinese nation. A series of major strategic thoughts, major theoretical views and major decision-making arrangements have been put forward, National defense and army building with a fundamental nature of the major issues, is the new situation to accelerate the modernization of national defense and military science guide. Military academies are the army personnel training base, is an important part of army building, is the cornerstone of army building development. Public Security Fire Force College (Public Security Fire Force College), as an active school, as the national fire brigade commander of the grassroots level of the cradle, as the only one to train grassroots command of professional schools, The battlefield, for the troops, around the actual engage in teaching, focusing on the fight for talent, and strive to improve the quality of running a new level, to achieve strong military dream to provide a strong fire support, Way.
\end{abstract}

\section{Soul: gun in my hands, I listen to the party command}

"Party command gun" is our party on the people's army absolute leadership principle of the image of the people's army is the army, the army of the soul, no matter what time can not have the slightest wavering.

1.1 Climbing the lifeline of ideological and political education. "Our party has always believed that the mastery of ideological education is the central part of the great political struggle of the whole party; ideological and political work is the lifeline of economic work and all other work." Adhere to the political police, political school is Kunming Fire Command School The core of education, ideological and political construction is the school's first school, cast loyalty to the police is a constant belief in the school. We must thoroughly carry out the ideals and beliefs and loyalty mission education, and profoundly grasp the spirit of the series of speeches of the General Secretary of the General Staff, guide the officers and soldiers, keep track of the strong military goals, strengthen the faith of the strong army, devote themselves to the practice of strengthening the army and unswervingly uphold the fundamental Principles and systems, to continue to cultivate the core values of contemporary revolutionary soldiers, to lay the foundation of thinking, and always maintain loyalty to the party, loyal to the motherland, loyal to the people's political character.

1.2 Clutching the cadre team building example. "Soldiers raging one, will be raging", to train the command of the party command of outstanding commanders, run first-class fire command institutions, can not do without the school cadres to build carefully. Among them, the teacher team determines the knowledge structure and ability level of the trainees, the quality of the cadre of the student team directly affects the quality of the students. And both at the same time for the growth of students to establish a good example of exemplary role for the students firm political position, loyalty to fulfill the party and the people to give the sacred duty plays a subtle role. To carefully build an "entrepreneurial, 
industry, education, dedication," the cadre teacher team, to "rule the military first governor, Yan Bingxian on the" concept throughout the cadre management, so that the majority of students learn Have an example, always remember to listen to the party command the same army soul.

1.3 Clinging to military political discipline zero tolerance. Listen to the party command is not an empty slogan, in the internalization of the heart at the same time, need to rely on strict political discipline to ensure. To firmly establish the "discipline is a block of iron, who touched the blood; discipline is a block of steel, who touched who was injured." Ideas, always adhere to the "first in the army, strict forces, higher than the troops" principle pay close attention to the school Discipline construction, and strive to do the political requirements of strict, strict governance, strict discipline, strict implementation of the system, strict political discipline, discipline, work discipline, always strict accordance with the law as a global, basic, long-term work Throughout the work, the implementation of the letter, the formation of all regulations by the regulations management force, according to school rules and regulations and rules and regulations in charge of a good atmosphere, to ensure the smooth flow of orders to ensure that the troops are highly centralized And safe and stable.

\section{Sweep: cast a sword, hard fire lion}

As a cradle to train the national fire brigade commanders, we should adhere to the battlefield, face the army, carry out teaching around the actual combat, focus on the education of talent, so that the training of students in line with the construction and needs of the fire, and strive to improve the quality of a school New level, out of a conducive to boost the development of new ways of firefighting talent.

2.1 Focus on actual combat. To focus on the needs of the first job, combined with the current size of the school and the characteristics of students, closely linked to the actual situation of grass-roots units to enhance the relevance and applicability of personnel training, and actively explore and sum up the law of education and teaching, to focus on combat. We should strive to practice the teaching philosophy of "teaching for war, learning for war and practicing war"; we must firmly establish the competency of teaching for firefighting, the benchmark of cultivating the satisfaction of grassroots units; and earnestly increase the practical training facilities Construction efforts; to modify and improve the focus of the actual combat personnel training teaching management mechanism, a steady stream of delivery for the grassroots needs, close to the times, the motherland needs, close to the people need fire command talent.

2.2 To the introduction of colleges and universities. "Talent is strong cause, talent is the army Xing", to firmly establish the "human resources is the first resource", "everyone can be talented", "talent priority development", "talent to use", " The combination of "individual development and group building", "combination of top-notch talent and growth talents", "combination of academic talents and management talents", "ideological and political construction and" Business capacity building combination of "four combination, vigorously implement the strategy of talent Xing school. To follow the law of higher education, vigorously the introduction of doctorate or master's degrees, and other personnel, solidly promote the construction of qualified personnel, the formation of a high level of education, teaching and research ability, reasonable structure, reserve forces sufficient teachers. At the same time, to encourage cadres, teachers through participation in business training, academic exchanges, to participate in vocational qualification examination and other forms, and constantly improve their own theoretical practice literacy.

2.3 To learn from the place. "Communication is a long time to learn the weapon, to continue to send research groups to the grassroots units to conduct research and study; select the actual combat experience of the instructors to come to the school, School teaching, so that classroom teaching closer to the actual combat, close to the first job requirements of students. From the various aspects to strengthen the teaching and practice of contact, to promote the school teachers in the field of fire the latest academic trends and development direction for cadres and teachers to provide a platform for learning and exchange, so as to effectively promote the development of teaching and research and personnel training quality improvement. 


\section{Ram base: tree fine style, Bao army character}

Excellent style is an important guarantee for the pursuit of strong military goals.

3.1 To carry forward the breeze righteousness. Vigorously carry forward the fine tradition of our party and our army, resolutely carry out the CPC Central Committee and the Central Military Commission on the improvement of style of a series of system requirements, vigorously carry forward the spirit of hard work, and firmly establish the idea of tight days, thrifty work to prevent extravagance and waste. Adhere to the hard work, against extravagance and waste, insist on seeking truth and being pragmatic, against formalism, adhere to clean and honest, against the abuse of power. Conscientiously implement the instructions of the General Secretary on the implementation of conservation, against the spirit of the instructions. With the system to control the right, with good power, and strive to form a mechanism that does not dare to rot, can not corrupt the prevention mechanism, not perishable protection mechanism. To establish the decision-making power, the implementation of the right to co-ordination and mutual control of the system of mutual restraint, build a clean line.

3.2 To cultivate fine school spirit. Military school spirit is directly affected the quality of student training, student style has a direct impact on the strength of the troops, to a large extent determine the style and combat effectiveness of the troops. Therefore, it is necessary to cultivate excellent school spirit as a basic project to carry out long-term unremitting efforts to carry out ideals and beliefs and loyalty mission education, unswervingly adhere to the party's absolute leadership of the armed forces of the fundamental principles and systems, lay the foundation of thinking, Loyal to the motherland, loyal to the people's political qualities. To adhere to the strict management of the school, strict discipline, strict study, in accordance with standards higher than the troops, strict management of the troops, the action ahead of the troops to strengthen and promote the school regularization. Continuously strengthen the teaching style, style of study and style of study, correct academic atmosphere, cultivate excellent school spirit, and create a good environment for educating people.

3.3 To implement sincere troops. Lead in your sincere dedication in the heart. "In the attitude of the soldiers in the correct attitude, in the military and educated soldiers in the soldiers, in the sincere love of Bingbing soldiers." We must vigorously create a "open mind, frankly meet, heart to heart, and seek common development" good atmosphere; to carry out various forms of regular ideological education, psychological education and psychological training, to improve the officers and men, Know the ability to enhance the level of self-regulation; to vigorously create a strong learning atmosphere, carefully arranged for cultural and entertainment, rich police camp culture. So that officers and soldiers, students in the camp activities, cultural and entertainment to achieve growth and progress in place, the ideological point in place, the actual difficulties in place, in full of truth and love of the harmonious police camp, and always maintain a stable mood and positive Optimism.

\section{References}

[1] Central Literature Research Office. "Xi Jinping on the realization of the great rejuvenation of the Chinese nation in China excerpts." 2014

[2] Xi Jinping. Adhere to the goal of a strong army to guide the reform around the goal of strengthening the military, to build a solid defense and strong military to provide a strong system support. 